\title{
A short Study of Indigenouse Social Movments and the Political Ecology in Mexico and Latin America
}

\author{
José G. Vargas Hernández, MBA, Ph.D. \\ Research Professor, Member of the National System of Researchers \\ Department of Marketing and International Business \\ University Center for Economic and Administrative Sciences U of G. \\ Peripherals Norte 799 Building G-306, Zapopan, Jalisco CP 45,100; Mexico \\ Tel and fax: 52-33-3770-3343 ext 5097 \\ E-mail: josevargas@cucea.udg.mx,jgvh0811@yahoo.com,jvargas2006@gmail.com
}

\author{
Mohammad Reza Noruzi \\ Executive Master Business Administration, EMBA \\ Islamic Azad University, Kaleibar, Iran \\ Faculty of Humanity Sciences, Department of Management and Accounting \\ Young Researchers Club Member, IAU Bonab, Iran \\ Tel: 98- 426-422-4915 Fax: 98-426- 422-4917 \\ E-mail: mr.noruzi.pnu@gmail.com
}

\begin{abstract}
Struggles of traditional movements have become blurred in the face of globalization intersecting with new demands and causes revolving around globalization, such as indigenous, women and human rights, environment, etc. The internationalization of civil society refers to cross-border linkages established by social movement organizations in peace, human rights, and environmental, gender, and labor, indigenous and other social movements.

This paper aims to analyze the historical social approach and under the frame of indigenous political ecology of social movements for recognition of indigenous rights in contemporary Mexico.
\end{abstract}

Keywords: Social movments, Mexico, Indigenous right, Recognition, Contemporary Mexico 


\section{Introducction: Indigenous movements}

Social movements cut across social class, ethnicity, levels of education, urban-rural, etc., and across all levels, local, state, national, regional, and international and global, forming connections between environment and development, health, civil rights, or indigenous rights (Keck and Sikkink, 1992; Brecher and Costello, 1994; Carruthers, 1995). Cultural theories about agency and subjectivity explain what social movements are doing.

Evers (1985:43) lists new social movements that includes squatters' groups, neighborhood councils, church-sponsored “ecclesiastical base communities" (CEBs), indigenous associations, women's organizations, human rights committees, youth groups, popular cultural and artistic activities. Also Evers considers literacy groups, coalitions for tile defense of regional traditions, environmental movements, a patchwork of self-help groupings among unemployed and poor people, “workers' associations organizing independently and even in opposition to traditional trade union structures".

Class and ethnic conflicts are that at the base of the struggle for identity of the indigenous movements that has its roots during the colonial period. The indigenous movement is not homogeneous and does not include all ethnic groups in the country, but it has many different expressions and encompasses different entities at local, regional and national levels. Movements at local levels are based on their ethnicity and community with limited mobilization. At regional level are integrated associations of ethnic groups.

Indigenous movements have similar concerns like other social movements that seek to change either society itself or the position of the group in society. Indigenous movements are characterized as process of national construction in search of collective identities looking at shared social identity based in cultural tradition.

Indigenous movements are shaped by the struggle for identity and the need to open a space for survival within the national political, economic and social environment. Indigenous social movements reflect discontinuous social change in periods of cultural and ideational crises. When ideational cycles overlap with waves of social protest movements, it is hard to demonstrate that the ups and downs of indigenous social movements coincide with an underlying ideational cycle and their identity over history. Movements emerge from the cycle of action -reform -action more entrenched within the communities (Tarrow, 1996; Maguire, 1996).

Whether the new social movements construct "new identities" rooted in the past, is a dilemma that arises with respect to indigenous movements that look to pre colonial times to propose a new kind of community.

There are complex difference and similarities between the North American indigenous movements and the Mexican indigenous movements.

\section{Indigenous political ecology}

The struggle for the recognition of indigenous rights is one of the most important social movements in Mexico. Among the indigenous leadership, the cooperative work has sparked 
the emergence of a technobureaucry of human rights and ethnodevelopment from government and international financial institutions programs. Movement leaders in such positions may enhance prestige of his own movement, hold accountable to his supporters and maintain close ties with party leaders.

It is still early evaluate the extent to which the EZLN movement is achieving change of cultural politics through elements that are part of the movement's history, such as radical democratic and autonomy practices, claims to indigenous identity, traditions and dignity. The indigenous movement maintains some levels of autonomy and has increased their capacity to bargain with the state. CONACAMI's presence in Ecuador is the only indigenous, autonomous, and independent organization.

Social movement analysts overlooked the practice of indigenous political ecology and the social movement action that social movements crate for meaningful political spaces as a component of negotiation between social movements and the state to secure benefits and to enhance the capacity of social movement organizations vis-a-vis the state.

There have been sharp debates within environmental movements over what should be understood for sustainable development and a relative lack of research on contemporary movements to protect the environment initiated by non-indigenous actors.

The Mexican environmental and indigenous movements focused on agriculture and the quest for sustainable alternatives, struggle to revalidate, revitalize and integrate traditional ecological knowledge into grassroots development projects. The preservation of species diversity is intrinsic to sustainable development and to environmental movements and international indigenous rights movement. An environmental movement in Southern Mexico and Central America pretends to preserve the wealth of biodiversity. Social movements in Mexico and around the world have raised the issues to control seeds and medicinal plants at different international conventions.

Agrarian and ethnic movements are conscious of the struggle for identity and began to state their demands as rights; land rights, labour rights or educational rights. Agroecological experimentation is fostered by state agencies that maintain linkages to activists in the peasant or environmental movements. Ecological social movements are intrinsically multi-sectoral, fostering linkages between indigenous, peasant, public health, labor, student, and urban popular movements. Ecological social movements articulate concerns and issues of other social movements.

Carruthers (1996) analyses cross-movement alliance formation between contemporary environmental groups, formed by the urban, educated middle class, which have found a convergence of interest with existing peasant and indigenous organizations of the most marginalized segment of Mexico's rural poor. Local indigenous and environmental movements are peaceful and unarmed, and draw on legal instruments, build ties with NGOs, churches and the scientific community.

The advocacy NGOs which are players on the border in the areas of environmental threats, the environmental justice movement, human rights, indigenous rights, and so forth. Alliances 
of environmental, agroecology and indigenous social movements fosters and strengthens linkages between grassroots organizations (GROs) that represent existing indigenous, peasant, and smallholders' organizations, and grassroots support organizations (GRSOs) which represent the applied face of the Mexican environmental and agroecology movements.

NAFTA has created mechanisms to deal with environmental hazards in the form of legal agreements and less formal non-binding agreements such as grass -roots movements on both sides of the border. NAFTA has precipitated an indigenous environmental movement while raising the level of awareness of environmental problems.

The ideology of indigenous movements switch between Neoliberalism and the Left. The Zapatistas have positioned themselves in dialogue with anti-neoliberal social movements in Mexico and around the world. The EZLN offers a coherent alternative to social movements in Mexico. For the Ecuadorian indigenous movement, social mobilizations achieved victories against the international financial organizations and their local allies, forcing the continuation of neoliberal economic policies.

\section{Social movements for recognition of indigenous rights}

Indigenous people created and participated in unions, political parties or cooperatives that, until the 1980s, did not articulate their demands in terms of their identity; rather they tended to identify themselves as peasant organizations (Yashar, 1998; Albó, 1999). After 1980, indigenous movements actively participated in the democratization process of Latin America (Diaz Polanco, 1997; Van Cott, 1994; Ramos, 1998; Horst, 1998; Warren, 1998). The renewal for indigenous movements across Mexico began with the 1987 publication of México Profundo (Deep Mexico: A Civilization Denied).

Movements at local levels are based on their ethnicity and community with limited mobilization. At regional level are integrated associations of ethnic groups and at national level the indigenous movement began in 1975 with indigenous organizations, such as the National Council of Indigenous People (NCPI) and the National Association of Bilingual Teachers.

Indigenous movements are shaped by the struggle for identity and the need to open a space for survival within the national political, economic and social environment. Class and ethnic conflicts are at the base of the struggle for identity of the indigenous movements. This struggle has its roots during the colonial period. Although indigenous movements have an ethnic component, they share common features with other social movements.

Indigenous movements' participation in the democratization movements adopts organizational forms to establish relationships of control and input with the political and judicial processes. The organization affects them in such a way that they can further their claims through political parties, NGOs, etc. with direct access to the decision-making processes at different levels of government. The inward strategic orientation of indigenous movements towards the national context depends on the level of control and input. The demographic weight of indigenous movements is nationally and regionally important. 
Indigenous movements have recoursed to ambiguous norms about human rights, environmental sustainability and cultural diversity. The Mexican environmental and indigenous movements focused on agriculture and the quest for sustainable alternatives, struggle to revalidate, revitalize and integrate traditional ecological knowledge into grassroots development projects.

The preservation of species diversity is intrinsic to sustainable development and to environmental movements and international indigenous rights movement. Agrarian and ethnic movements are conscious of the struggle for identity and began to state their demands as rights, land rights, labor rights or educational rights. Indigenous movements need to follow more of a multi-pronged strategy of lobbying, alliance making, appealing to courts, and public campaigns than a legal alternative which is besieged by traps and counterproductive results.

Carruthers (1995) uses the term "indigenous political ecology" to refer to the consolidation of social movement alliances based in an effort to preserve, defend, apply and integrate Traditional Ecological Knowledge (TEK) embedded in indigenous and peasant culture and practice into grassroots development efforts. Indigenous ecology refers to alliances between environmental and indigenous social movement organizations. Internationalization of the indigenous ecology movement reveals ongoing tension between two contending social movement visions, one of which is the individual's social movement activity.

Carruthers (1996) analyses cross-movement alliance formation between contemporary environmental groups, formed by the urban, educated middle class, which have found a convergence of interest with existing peasant and indigenous organizations of the most marginalized segment of Mexico’s rural poor.

A multi-pronged strategy includes alliances with other social movements is dependent on the existence of points of common interest. Indigenous communities ally with environmental and human rights movements to lobby and exert pressures on national governments. Alliance of Indigenous movements and alliances may have some possibilities of reshaping of current structures of governance.

Agroecology, as a social movement, seeks to rescue traditional practices, and protect biological and cultural diversity to bring together First World and Third World forms of environmentalism. The emergence of agroecology movement in Mexico is fuelled by high ecological costs of industrial agriculture. Agroecological experimentation is fostered by state agencies that maintain linkages to activists in the peasant or environmental movements.

Alliances of environmental, agroecology and indigenous social movements fosters and strengthens linkages between Grassroots Organizations (GROs) that represent existing indigenous, peasant, and smallholders' organizations, and Grassroots Support Organizations (GRSOs) which represent the applied face of the Mexican environmental and agroecology movements. A GRSO "is a developmental civic entity that provides services for and channels resources to local groups of disadvantaged rural or urban households and individuals" (Bendahmane, 1991, 31). 
The indigenous communities are cohesively responding to the ethnic conflict as one of the most significant social movements in Mexico's history to the surprise of other social actors, such as government, politicians, analysts and academics. Mejía Pineros and Sarmiento Silva (1987), Moguel, Botey, and Hernández, Eds (1992) and Warman and Argueta, Eds. (1993) have researched regional indigenous movements in Mexico, as well as the journals Ojarasca and Cuadernos Agrarios. The priority of the indigenous movement is the bilingual educational programs or recovery of traditional cultures.

The 1980s was a time of social mobilization and expansion in Mexican social indigenous and peasant movements. Indigenous civil society, in some regions richly textured and thin, heavily structured by clienteles in others, reflect the historical legacies of both past movements from below and openings from above (Fox, 1997). Some local movements are defections from the ruling corporatist party while others emerged from an opening within the ruling political class in the early 1970s and have independently promoted bottom-up strong ethnic identity-based mobilization, as in the case of the democratization of Oaxaca's Zapotec market town of Juchitán.

The local movement development increased with mobilization from below, from political alliances and from reform-oriented elites controlled state politics. Social movements often attempt to occupy the cracks in the system from below, demanding access to the state while articulating their own interests.

Different positions about the new relation between developmental and environmental concerns became more visible as different organizations, institutions and movements established connections with each other. Indigenous communities and their alliances with non-Indigenous communities and wider movements have transformative effects on the structures of governance. The contradiction between the growing pressures on international financial institutions and the state widened with the consolidation in the 1990s of the transnational environmentalist movement and the indigenous communities' rights to sustain their own life projects were legitimated and the international indigenous movement and environmentalism was consolidated.

Several facts have rising consciousness of the new indigenous movement. American indigenous movements started in 1992 with the legitimacy to the heightened indigenous issues and international awareness coming out from the boost of the 500th Anniversary of Columbus's "discovery" of the Americas. The 1992 have been a time of renewal for indigenous movements when Rigoberta Menchú, a Mayan Woman was awarded the 1992 Nobel Peace Prize for her role as a symbol of the rising consciousness of the new indigenous movement.

The celebrations reinvigorated organizations and Indian movement ties, creating new alliances between indigenous groups, pan-Indian movements, NGOs, environmental groups and others. This and other events created an environment in Mexico for the formation of new indigenous movement organizations and new alliances between indigenous movements 
The indigenous social movements gain access to the political sphere based on solidarity among members and the capacity to create new forms of social relations and practice, like shared antagonism towards others. Power is not central, defined as a "continuing overt relationship of conflict between collective actors and authorities" (Evers, 1985). However, collective actors are prone to disperse, fragmented and atomized, into networks, which quickly disappear from political relevance into sects, emotional support circles and therapy groups.

The struggle of indigenous people of Chihuahua, the Taraumaras is articulated against illegal forestry practices, in particular, water and biodiversity. An indigenous, religious and social movement, the Civil Society Las Abejas, emerged in 1992 as a coalition of local indigenous Maya-Tzotzil communities who united to solve land conflicts. The Land Research Action Network was launched in Chiapas to mobilize people in support of popular movements who are struggling for access to land. Identity among communities provides emotional involvement in collective action.

In January of 1994, the Zapatista uprising of Mayan indigenous communities in Chiapas received solidarity from indigenous and peasant movement organizations, networks, alliances, and coalitions. The Zapatista guerrilla movement that emerged in Chiapas in 1994 has triggered social movements in Mexico and abroad, to emphasize the increasing levels of poverty under the neoliberal economic policy and. demanding a more equitable income distribution.

As a resistance movement, the Zapatista uprising in Chiapas have been successful using the slogan ¡Basta ya! (Enough!) and presenting their 11-word program to the Mexican government: “Trabajo, Tierra, Techo, Pan, Salud, Educación, Democracia, Libertad, Paz, Independencia, y Justica” (work, land, shelter, bread, health, education, democracy, liberty, peace, independence, and justice).

Local indigenous and environmental movements are peaceful and unarmed, and draw on legal instruments, build ties with NGOs, churches and the scientific community. The Zapatista movement represents grassroots organizations, which can broaden and deepen without external alliances. In 1994, diverse local civic movements that included human rights movements, cooperatives, and ethnic rights emerged throughout the region in conflict in Chiapaz, ejected most of the ruling party mayors of municipalities and instead installed pluralistic town councils.

Las Abejas movement is an expression of the "civil society" movement comprising of several peasant, indigenous and local non-governmental organizations. Since 1997, when 45 members were massacred in Acteal, human rights organizations support the use of nonviolent methods of conflict resolution. The interactions among members form a unique "global syncretic identity," which inspires the movement in its collective action of resistance against displacement and military land invasion.

As a social movement, the EZLN is distinguishable from other popular movements in Mexico having actively mobilized not only the indigenous groups but also other large groups of 
economic, social and political actors. Indigenous communities re-focus on traditional values and transform old meanings in order to continue with their land struggle. The EZLN can strategically develop either into a new political movement or into an indigenous autonomy movement.

The Zapatista movement is considered a transnational rhizomes or social netwars weaving a global electronic fabric of struggle and mounting a social netwar against a state lagging at democratization. The Zapatista Rebellion is a prototype for social netwar in the 21st century, in which almost every aspect of modern computer communications have been used.

There is new capacity for this and other social movements to communicate across borders and to operate at a transnational level. The analyses of this movement have recognized how the content of the rhizomatic or networking forms of social mobilization, pulling together grassroots movements against the current political and economic order in Mexico and the world and of facilitating alternative approaches to social organization. Governments should learn to counter such social movements and have to improve its ability to wage counter-netwar.

The unprecedented success of EZLN as a new social movement has been attributed to its post modernity. The EZLN as a new social movement has been characterized as the first "postmodern" peasant rebellion because of the sophisticated communication techniques. A Mexican analyst, Gustavo Esteva, posed the question, "Is ours the last Central American guerrilla war, or has the new postmodern revolutionary era begun?” (Cockburn, 1994: 404).

Through creative use of images and information, indigenous people have turned marginality and poverty into their greatest strength on the emergence of "internationalized," identity-based movements. Kelley (2002: 9) states that "how oppressed we are or that merely chronicles the [follies] of radical movements doesn't seem very useful... Progressive social movements do not simply produce statistics and narratives of oppression; rather, the best ones do what great poetry always does: transport us to another place, compel us to relive horrors and, more importantly, enable us to imagine a new society”

Chiapas revolt remains an indigenous » revolt because it's the EZLN revolt supported with the rest of social movements in Mexico. It is still early evaluate the extent to which the EZLN movement is achieving change of cultural politics through elements that are part of the movement's history, such as radical democratic and autonomy practices, claims to indigenous identity, traditions and dignity. The indigenous movement maintains some levels of autonomy and has increased their capacity to bargain with the state

The Zapatistas have positioned themselves in dialogue with anti-neoliberal social movements in Mexico and around the world. The EZLN offers a coherent alternative to social movements in Mexico. The National Indigenous Congress (CNI) began in 1996 to bring the indigenous movements aligned with the Zapatistas together under the assumption of creating an understanding of a collective sense of self in movement. This was in contrast to homogenizing mestizaje (mixed-race) and identity categories so as to gain recognition as citizens (Rosaldo, 2000). 
Sustained indigenous social movements in Mexico and Indigenous peoples have an important role to achieve resolutions and demands of the National Indigenous Congress and social movements in Mexico aimed to nurtur and conserve natural and cultural biodiversity. An environmental movement in Southern Mexico and Central America pretends to preserve the wealth of biodiversity. Social movements in Mexico and around the world have raised the issues to control seeds and medicinal plants at different international conventions.

Internationalization of the Mexican indigenous social movement finds support in around the world. The Binational Mixtec-Zapotec Front, (FM-ZB) based in California, organize migrant farmworkers of Oaxacan origin and promotes indigenous resistance and worker and human rights and sustainable agricultural development projects.

There are other binational movements, such as the Frente Indigena Oaxaqueno Binacional, which is comprised, of Mexican and U.S. based indigenous and migrant workers' organizations. These migrant organizations include the CCPM (Popular Mixtec Civic Committee), the ORO (Oaxacan Regional Organization), the COTLA (Tlacolulense Community in Los Angeles), the OPEO (Organization of Exploited and Oppressed Peoples), etc.

Some of these movements maintain affiliations with the César Chávez's United Farmworkers of America, and the San Francisco based NGO AT-Work (The Appropriate Technology Working Group, of the Earth Island Institute). Neither the indigenous movement, nor other social movements in Mexico, has an ideological support for drug prohibition.

\section{Strategies}

The Zapatista Rebellion is a prototype for social netwar in the 21st century, in which almost every aspect of modern computer communications have been used. The analyses of this movement have recognizes how the content of the rhizomatic or networking forms of social mobilization, pulling together grassroots movements against the current political and economic order in Mexico and the world and of facilitating alternative approaches to social organization. Governments should learn to counter such social movements and have to improve its ability to wage counter-netwar.

The unprecedented success of EZLN as a new social movement has been attributed to its post modernity. The EZLN as a new social movement has been characterized as the first "postmodern" peasant rebellion because the sophisticated communication techniques. A Mexican analyst, Gustavo Esteva, posed the question, "Is ours the last Central American guerrilla war, or has the new postmodern revolutionary era begun?” (Cockburn, 1994:404).

The inward strategic orientation of indigenous movements towards the national context depends of the level of control and input. The EZLN can strategically develop either into a new political movement or into an indigenous autonomy movement. There is a larger movement opposing to a top-down Plan Puebla-Panamá that could lead to a more inclusive strategy of alternative development. Many indigenous communities, social movements and NGOs have condemned the greenwash of the massive Plan Puebla Panama. The strategy designed to pursue their demands and management of relationship with state institutions are 
two factors for indigenous movements to succeed.

Indigenous movements need to follow more a multi-pronged strategy of lobbying, alliance making, appealing to courts, and public campaigns than a legal alternative which is besieged by traps and counterproductive results. A multi-pronged strategy includes alliances with other social movements is dependent on the existence of points of common interest. Indigenous communities ally with environmental and human rights movements to lobby and exert pressures on national governments. Alliance of Indigenous movements and alliances may have some possibilities of reshaping of current structures of governance.

Through creative use of images and information, indigenous people have turned marginality and poverty into their greatest strength on the emergence of "internationalized," identity-based movements. Kelley (2002: 9) states that "how oppressed we are or that merely chronicles the [follies] of radical movements doesn't seem very useful... Progressive social movements do not simply produce statistics and narratives of oppression; rather, the best ones do what great poetry always does: transport us to another place, compel us to relive horrors and, more importantly, enable us to imagine a new society”.

Inspired by the Zapatista's “Other Campaign” in Mexico, the indigenous movement CONAIE is centered on creating another policy.

\section{Discussion}

Indigenous social movements are means of developing social identity and democratic recovery while organizing political mobilization against dictatorship. Indigenous movements' participation in the democratization movements adopt organizational forms to establish relationships of control and input with the political and judicial processes that affect them. In this way, the indigenous movements can further their claims through political parties, NGOs, etc., with direct access to the decision-making processes at the different levels of government.

Indigenous communities and their alliances with non-Indigenous communities and wider movements have transformative effects on the structures of governance. Indigenous communities re-focus on traditional values and transform old meanings in order to continue with their land struggle.

Globalization has played a more active participation in indigenous movements in the increasing global civil society. Indigenous civil society, in some regions richly textured and thin, heavily structured by clientelism in others, reflect the historical legacies of both past movements from below and openings from above (Fox, 1997). In bottom-up consolidation of civil society in indigenous regions, external allies may be crucial to the movement's capacity to survive. (Collier and Quaratiello, 1994; Fox, 1994; Harvey, 1994, and Hernández, 1994)

The demographic weight of indigenous movements is nationally and regionally important.

The contemporary indigenous movements are focused on differences while the liberal discourse homogeneizes. However, the ethnic component of indigenous movements leads to the conclusion that they cannot be studied like other social movements under the theoretical 
approach of Social Movement Theory. Although indigenous movements have an ethnic component, they share common features with other social movements.

\section{References}

Bendahmane, Diane B. (1991). Performance review for NGOs. Grassroots Development 15, no. 2: 31-37. America-Part 2, Cambridge: Cambridge University Press, pp. 765-869.

Brecher, Jeremy, and Tim Costello. (1994). Global Village or Global Pillage? Economic Reconstruction from the Bottom Up. Boston: South End Press.

Carruthers D. V. (1996). "Indigenous ecology and the politics of linkage in Mexican social movements”. Third World Quarterly, Vol 17, No 5, pp 1007士 1028, 1996

Carruthers, David. (1995). "The Political Ecology of Indigenous Mexico: Social Mobilization and State Reform." Ph.D. diss., University of Oregon, Eugene, Oregon, USA.

Diaz Polanco, H. (1997). Indigenous Peoples in Latin America: The Quest for Self-Determination, Boulder, CO: Westview Press.

Evers, Tilman. (1985). "Identity: The Hidden Side of New Social Movements in Latin America,"in David Slater, ed., New Social Movements and the State in Latin America. Amsterdam: CEDLA, 1985.

Fox, Jonathan. (1997). "The difficult transition from clientelism to citizenship: Lessons from Mexico”, in Chalmers, Douglas A. Vilas, Carlos M. Hite, Katherine, Martin, Scott B.,Piester, Kerianne Segarra, Monique. (1997). The new politics of inequality in Latin Amerca Rethinking participation and representation. Oxford University Press.

Horst, Rene. (1998). 'Authoritarianism, Indigenous resistance and religious missions: Paraguay, 1958-1992’, Ph.D. thesis, Department of History, Indiana University.

Keck, Margaret, and Kathryn Sikkink. (1992). International issue networks in the environment and human rights. Paper presented at the XVII International Congress of the Latin American Studies Association, (24-27 September), Los Angeles, CA.

Kelley, Robin D.G. (2002). Freedom Dreams: The Black Radical Imagination. Boston: Beacon Press.

Maguire, Diarmuid. (1996). Irish Republicans since 1968: From Rebels to Reformers? Sydney: University of Sydney.

Rosaldo, Renato. (2000). "La pertenencia no es un lujo: procesos de ciudadanía cultural dentro de una sociedad multicultural,” in Desacatos. Ciudad de Mexico: CIESAS,Spring, pp. 39-49. Speed, Shannon.

Tarrow, Sidney. (1996). "States and Opportunities: The Political Structuring of Social Movements” in Doug McAdam; John D. McCarthy \& Mayer N. Zald (eds) op.cit.

Van Cott, D. (ed.) (1994). Indigenous Peoples and Democracy in Latin America, New York: St Martin's Press. 


\section{Macrothink}

Journal of Management Research ISSN 1941-899X 2010, Vol. 2, No. 2: E5

Warren, Kay B. (1998). Indigenous Movements and Their Critics: Pan-Maya Activism in Guatemala, Princeton: Princeton University Press.

Yashar, D. (1998). 'Indigenous movements and democracy in Latin America', Comparative Politics, vol. 31, no. 1, pp. 23-43. 